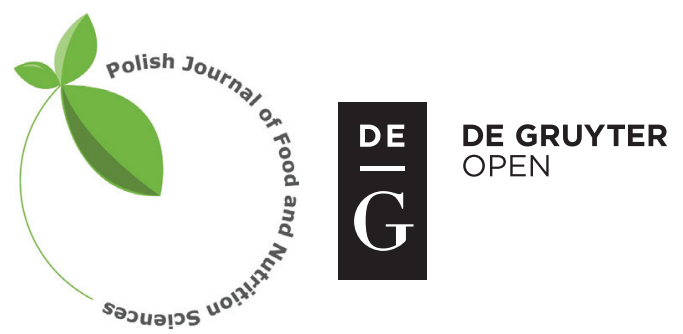

Pol. J. Food Nutr. Sci., 2017, Vol. 67, No. 4, pp. 265-274

DOI: $10.1515 /$ pjfns-2016-0020 http://journal.pan.olsztyn.pl

Original research article

Section: Food Technology

\title{
Effect of Rosemary Transglutaminase on Yoghurt Fortified with Whey Protein Isolate
}

\author{
Osama Ibrahim ${ }^{1, *}$, Pawel Glibowski ${ }^{2}$, Maher Nour ${ }^{3}$, Mahmoud El-Hofi ${ }^{1}$,El-Sayed El-Tanboly ${ }^{1}$, Nabil Abd-Rabou ${ }^{1}$ \\ ${ }^{1}$ Dairy Sciences Department, National Research Centre in Dokki, Cairo, Egypt \\ ${ }^{2}$ Department of Biotechnology, Human Nutrition and Food Raw Material Science, University of Life Sciences in Lublin, \\ Skromna 8, 20-704 Lublin, Poland \\ ${ }^{3}$ Dairy Department, Faculty of Agriculture, Al-Azhar University, Cairo, Egypt
}

Key words: transglutaminase, rosemary, cross-linking, whey proteins, rheology, gelation

Rosemary (Rosmarinus officinalis L.) transglutaminase (RTGase) was used to cross-link whey protein isolate (WPI) and its ability to induce gelation was investigated. The rheological and textural properties of WPI were improved with RTGase treatment. Set-type yoghurts fortified with $1 \%$ WPI powder treated with RTGase at the level of 2.5 and 10 unit/g protein were studied. Chemical, rheological, textural and organoleptic properties of the yoghurt treated with RTGase were better than these of the control yoghurt.

\section{INTRODUCTION}

Consumption of fermented milks including yoghurt as a very important dairy product around the world has increased dramatically over the past three decades mainly due to the nutritional value and healthy aspects associated with these products [Kücükcetin, 2008].

The enzymatic cross-linking of proteins by means of transglutaminase (TGase, EC 2.3.2.13) allows a modification of their structure at a molecular level. TGase is an enzyme capable of catalyzing the cross-linking of proteins through an acyl transfer reaction using the $\gamma$-carboxamide group of peptide-bound glutamine residues as acyl donor and the $\varepsilon$-amino groups of lysine residues as acyl acceptor, intra-molecular and/ or inter-molecular cross-links (isopeptide bonds) are formed, resulting in the polymerization of proteins [Griffin et al., 2002; Ha \& Iuchi, 2003].

The functional effect of TGase cross-linking reaction can be used to introduce amino acids or peptides into protein for enhancing the nutritive value of food [Motoki \& Kumazawa, 2000]. Moreover, TGase covalent cross-links represent a promising tool in modification of functional properties of proteins such as solubility, emulsifying capacity, foaming and gelation properties of proteins intended for human consumption, where chemical reagents for protein modification are not acceptable [Li-Chan, 2004; Jaros et al., 2006]. TGase is classed as a processing aid by the European Union (EU regulation 1332/2008) and has 'generally recognized as safe (GRAS)' status in the USA [Loveday et al., 2013]. The en-

\footnotetext{
* Corresponding Author: E-mail: osama_nrc@hotmail.com (O. Ibrahim)

zyme has been used for modifying the functionalities of various proteins including soy proteins, myosin, gluten, globulin, casein, and whey proteins [Lin et al., 2007].

TGases are widespread in microorganisms, plants, vertebrate and invertebrate animals [Serafini-Fracassini \& Del Duca, 2008]. TGase activity has been found in higher and lower plants [Del Duca \& Serafini-Fracassini, 2005]. TGase activity has been detected in silver beet (Beta vulgaris L.) leaves [Signorini et al., 1991]. Kang \& Cho [1996] purified TGase from soybean (Glycine max) leaves. TGase was detected in root and shoot tissues of dicotyledonous [pea (Pisum sativum) and broad bean (Vicia faba)] and monocotyledonous [wheat (Triticum aestivum) and barley (Hordeum vulgare)] plants [Lilley et al., 1998]. Also, TGase was detected in the corolla of tobacco (Nicotiana tabacum) flowers and apple (Malus domestica) pollen [Serafini-Fracassini et al., 2002; Del Duca et al., 2009; Di Sandro et al., 2010].

El-Hofi et al. [2014] purified and characterized TGase from rosemary (Rosmarinus officinalis L.) leaves. Rosemary is a spice and medicinal herb widely used around the world as the natural antioxidant; it has been widely accepted as one of the spices with the highest antioxidant activity [Genena et al., 2008]. RTGase exhibited optimum activity at $\mathrm{pH}$ 7.0 and $55^{\circ} \mathrm{C}$ for the catalytic reaction of N-carbobenzoxy-L-glutaminylglycine and hydroxylamine [El-Hofi et al., 2014].

Multiple studies have been carried out for the enzymatic modification of whey protein through a catalyzed reaction of mTGase such as higher firmness and resistance of the protein gel [Eissa \& Khan, 2006], change of gel point temperature [Truong et al., 2004], and reducing syneresis of acid gels [Gauche et al., 2009]. 
Ozer et al. [2007] investigated the physical, chemical and sensory characteristics of non-fat yoghurts treated with mTGase at varying concentrations from 0 to $0.5 \mathrm{~g} / \mathrm{L}$ milk. Acid development rate was reduced with increasing mTGase doses. Cross-linking of milk proteins by mTGase had a growth-slowing effect on yoghurt starter bacteria, which was more pronounced at higher concentrations. Physical properties of the yoghurts were improved by mTGase throughout 21-day storage. Set-type yoghurts from goat's milk crosslinked by mTGase at the level of 1, 2 and 3 unit/g protein were produced and the treated yoghurts (fresh and stored) had higher sensory scores, higher readings for texture measurements (i.e. firmness) and a lower volume of syneresis than the control product [Domagała et al., 2013]. Iličić et al. [2014] studied the effect of different concentrations of TGase, 0.02, 0.06 and $0.12 \%(\mathrm{w} / \mathrm{w})-$ on the textural characteristics and flow properties of stirred probiotic yoghurt prepared from pasteurized skim milk.

Therefore, the aim of the present study was to investigate the rheological properties of a WPI solution treated with RTGase. Moreover, investigated was the ability of covalent cross-linking by the same enzyme to induce gelation of WPI and their rheological properties were monitored in the absence and presence of RTGase. Finally, rheological, chemical and organoleptic properties of set-type yoghurt fortified with WPI cross-linked with RTGase were studied.

\section{MATERIALS AND METHODS}

\section{Materials}

Whey protein isolate (WPI) (total protein content 90\%, w/w) was obtained from DAVISCO Food Ingredients International (LeSueur, MN, USA). Rosemary (Rosmarinus officinalis L.) was obtained from production and marketing of medicinal plants and their extracts unit, Medicinal and Aromatic Plants Research Department, National Research Centre, Egypt. Fresh cow milk was purchased from the local market in Lublin, Poland. N-carbobenzoxy-L-glutaminylglycine and hydroxylamine hydrochloride were purchased from Sigma-Aldrich, Steinheim, Germany. The yoghurt starter culture (DVS YC-X11 Yo-Flex Thermophilic Lactic Culture type Yoghurt CHR, Streptococcus thermophilus and Lactobacillus bulgaricus) was donated by Chr. Hansen, Poland. All other chemicals used were of analytical grade.

\section{Preparation of RTGase enzyme}

TGase enzyme extract was prepared from the rosemary (Rosmarinus officinalis L.) leaves according to El-Hofi et al. [2014]. The RTGase had an activity of $10 \mathrm{unit} / \mathrm{mL}$ (measured by hydroxamate method of Folk \& Cole [1966]). Each unit of TGase is defined in terms of its activity, which corresponds to the amount of the enzyme that catalyzes the reaction of hydroxylamine and $\mathrm{N}$-carbobenzoxy-L-glutaminylglycine to yield $1 \mu \mathrm{mol}$ of hydroxamic acid $/ \mathrm{min}$ at $37^{\circ} \mathrm{C}$.

\section{Preparation of protein samples treated with RTGase}

Protein solutions were prepared by dissolving WPI powder in distilled water to obtain a final concentration of $8 \%$ and stirring well before heating for approximately $1 \mathrm{~h}$ to en- sure complete solubility using a magnetic stirrer. WPI solutions were heated in test tubes in a controlled temperature water bath at $80^{\circ} \mathrm{C}$ for 30 min followed by rapidly cooling to 40 and $55^{\circ} \mathrm{C}$, and then RTGase enzyme was added in the concentration of 2.5, 5.0, 7.5 and 10 Unit per g protein and incubated for 30, 60, 90 and 120 min. After incubation, the samples were heated at $85^{\circ} \mathrm{C}$ for $5 \mathrm{~min}$ to deactivate the RTGase enzyme followed by cooling to $25^{\circ} \mathrm{C}$; the rheological measurements were carried out, in triplicate. Control samples were prepared as described above, except that the enzyme was omitted whereas water was added in the same volume of enzyme extract.

\section{Preparation of WPI gel by RTGase}

WPI solution samples were prepared as described above, and then the RTGase was added in the concentration of $(2.5 / 30,5.0 / 60,7.5 / 90,10 / 60$ and 120) unit per $g$ protein/min. After incubation, the samples were heated at $85^{\circ} \mathrm{C}$ for 5 min to deactivate the RTGase enzyme followed by cooling to $25^{\circ} \mathrm{C}$. In addition, $0.2 \mathrm{~mol} / \mathrm{L}$ of sodium chloride was added to all samples which were then stored for $24 \mathrm{~h}$ at $5^{\circ} \mathrm{C}$. The rheological measurements were carried out, in triplicate. Control samples were prepared as described above, except that the enzyme was omitted whereas water was added in the same volume of enzyme extract.

\section{Yoghurt manufacturing and enzymatic treatment with RTGase}

\section{Protein fortification of skim milk}

Fresh skim milk was fortified with 1\% WPI powder; the mixture was denominated as (Mix 1). Subsequently, the yoghurt milk was stirred well about 30 min using magnetic stirrer to homogeneity and complete hydration of all powder particles.

\section{Yoghurt fermentation and enzymatic cross-linking by RTGase}

The Mix 1 was heated to $80^{\circ} \mathrm{C}$ for $5 \mathrm{~min}$ to inactivate the indigenous TGase inhibitor in milk, followed by cooling to $55^{\circ} \mathrm{C}$, RTGase was added to each sample at a protein ratio of 2.5 and 10 unit per g protein for $30,60 \mathrm{~min}$, respectively prior to lactic culture addition; followed by heating to $90^{\circ} \mathrm{C}$ for $5 \mathrm{~min}$. Then lactic culture was added after the mixtures had been cooled to $42^{\circ} \mathrm{C}$ within $0.015 \%$ (w/v) of Streptococcus thermophilus and Lactobacillus bulgaricus. The cultured yoghurt milks were poured to $50 \mathrm{~mL}$ yoghurt jars and then incubated at $42^{\circ} \mathrm{C}$ in a thermostatic cabinet until the $\mathrm{pH}$ reached 4.6. After incubation, the yoghurt jars were cooled and stored at $5^{\circ} \mathrm{C}$ until analysis. Control samples were prepared without addition of RTGase whereas water was added in the same volume of enzyme extract, and the experiment was carried out in duplicate.

\section{Analytical techniques}

\section{Chemical characterization}

The following chemical analyses were carried out on the yoghurt samples, according to AOAC [1995]: moisture $(\%)$, ash (\%), total solids (\%), fat (\%) and total protein (\%). 
Acidity was determined as lactic acid (g/100 g) by titration with $1 / 9 \mathrm{~N} \mathrm{NaOH}$. The $\mathrm{pH}$ of the samples was measured by using a pH-meter (Hanna Instruments Model 170300, Ingold, Knick, Germany). All analyses were performed in triplicate and all experiments were repeated in two trials.

\section{Organoleptic properties evaluation}

The organoleptic properties of yoghurt samples were evaluated by a regular score panels chosen from the staff members of the National Research Centre. Yoghurt samples were evaluated for appearance (20 points), color (20 points), body and texture (20 points), flavor (20 points) and overall acceptability (20 points) according to Maifreni et al. [2002].

\section{Rheological measurements}

Rheological measurements were carried out using a Dynamic Rheometer Haake RS300 (Haake, Karlsruhe, Germany). Apparent viscosity and dynamic oscillatory rheometric measurements of the WPI solution or gel and yoghurt samples were determined at $20 \pm 1^{\circ} \mathrm{C}$ using a Dynamic Rheometer Haake RS300 (Haake, Karlsruhe, Germany). Temperature control was maintained by a Haake DC30 circulator water bath $($ Haake $\mathrm{GmbH})$. All rheological data were collected and calculated by Haake Rheowin software version 3.61.0004 (Haake, Karlsruhe, Germany). The samples were analyzed after their storage for $1 \mathrm{~h}$ at room temperature. The WPI solution samples were analyzed using a concentric-cylinder fixed cup (43 $\mathrm{mm}$ diameter) and rotating vane (22 $\mathrm{mm}$ diameter, $112 \mathrm{~mm}$ height) but the WPI gel and yoghurt samples were placed between parallel cone and plate and the gap between them was set to $1 \mathrm{~mm}$. The apparent viscosity was measured at $20 \mathrm{~s}^{-1}$ shear rate for $120 \mathrm{~s}$. The elastic storage modulus (G') and the viscous loss modulus (G') of the protein samples were monitored at $20 \pm 1^{\circ} \mathrm{C}$ in oscillatory mode with coaxial cylinder geometry. Frequency sweeps $(0.1-100 \mathrm{~Hz})$ were conducted at the strain corresponded to the maximum found within the linear viscoelastic region of the studied material. All rheological measurements were conducted at least in duplicate.

\section{Texture profile analysis}

For texture analysis, the WPI gel and yoghurt samples were prepared in plastic containers $(2.5 \mathrm{~cm}$ diameter $)$ of $50 \mathrm{~mL}$ by punching a cylindrical probe $(1 \mathrm{~cm}$ of diameter $)$ with the cross head speed $\left(1 \mathrm{~mm} \mathrm{~s}^{-1}\right)$ at $15 \mathrm{~mm}$ depth, using a TA-XT2i Texture Analyzer (Stable Micro systems, Godalming, England). The analysis was performed without removing the samples from the containers immediately after storage at room temperature for $1 \mathrm{~h}$. Two repetitions were done for each sample and all experiments were repeated in two trials.

\section{Statistical analysis}

Statistical analysis of the average values obtained from the chemical, rheological parameters and instrumental texture parameters data were analyzed by the Statistical Analysis System [SAS, 1990] using the ANOVA procedure for analysis of variance. The results were expressed as mean \pm standard error and the differences between means were tested for significance using Duncan's multiple range at $p \leq 0.05$.

\section{RESULTS AND DISCUSSION}

\section{Influence of RTGase on WPI solution}

Changes of apparent viscosity of the WPI solution (8\%) in the presence and absence of RTGase with different incubation temperature: 40 and $55^{\circ} \mathrm{C}$ are presented in Figures 1 and 2, respectively. The apparent viscosity of the enzyme-treated WPI solution was higher than that of the sample containing no TGase enzyme where the reaction catalyzed by TGase leads to the formation of high molecular weight polymers; it could be due to both inter- and intra-molecular bonds formation between the protein molecules [Ando et al., 1989]. Similar results showed an increase in viscosity with TGase treatment after heat treatment of WPI [Truong et al., 2004; Eissa \& Khan, 2006; Gauche et al., 2010] whereas these findings showed that $\beta$-lactoglobulin could be cross-linked using TGase into high molecular weight polymers with high viscosity. It could be suggested that the presence of TGase enzyme affected the physical interactions between protein molecules.

On the other hand, the results of incubation temperature effect on the viscosity of WPI solutions showed that the viscosity of the WPI treated with RTGase at $40^{\circ} \mathrm{C}$ was less than that of the samples treated at $55^{\circ} \mathrm{C}$, it could be due to the fact that the enzymatic treatment at $40^{\circ} \mathrm{C}$ was less favorable to hydrophobic interactions than the treatment at $50^{\circ} \mathrm{C}$ which strengthens the hydrophobic interactions at elevated temperatures [Fægemand \& Qvist, 1999; Wilcox \& Swaisgood, 2002]. Moreover, the higher viscosity of WPI solution at $55^{\circ} \mathrm{C}$ than $40^{\circ} \mathrm{C}$ could be due to RTGase optimum temperature was $55^{\circ} \mathrm{C}$.

\section{Influence of RTGase on WPI gel formation}

WPI (8\%) ability of gel formation was investigated when the WPI samples treated with different concentrations of RTGase were incubated at $40^{\circ} \mathrm{C}$ and $55^{\circ} \mathrm{C}$. Generally, as shown in Figure 3, apparent viscosity of the WPI gel treated with RTGase had higher values than those formed with no enzyme treatment. Also, the apparent viscosity of WPI gel cross-linked with RTGase incubated at $55^{\circ} \mathrm{C}$ was higher than $40^{\circ} \mathrm{C}$ and there were significant $(p \leq 0.05)$ differences between the treated WPI gel compared to untreated WPI gel at $55^{\circ} \mathrm{C}$ in all concentrations except at the level of 10 unit RTGase/g protein of WPI. These findings could be due to polymerization of WPI treated by RTGase enzyme compared to the sole addition of TGase. The gelation was observed visually in all samples when incubated for $24 \mathrm{~h}$ at $5^{\circ} \mathrm{C}$ after $0.2 \mathrm{~mol} / \mathrm{L} \mathrm{NaCl}$ addition. Similar observation had been noted by Truong et al. [2004], who reported that the protein network was partially formed during the enzymatic polymerization, requiring less heat for the protein gelation with TGase treatment whereas the gel point temperature of WPI solutions treated with 0.12 unit of immobilized TGase/g was slightly decreased. Gelation was observed visually in the enzyme-treated WPI samples containing dithiotreitol (DTT) at protein concentrations above $10 \%$ within 120 min using 10 unit TGase/g whey proteins [Færgemand et al., 1997].

Elastic modulus $\left(G^{\prime}\right)$ and viscous modulus (G') of WPI gel were shown in Figures 4 and 5, respectively. G' and G', 

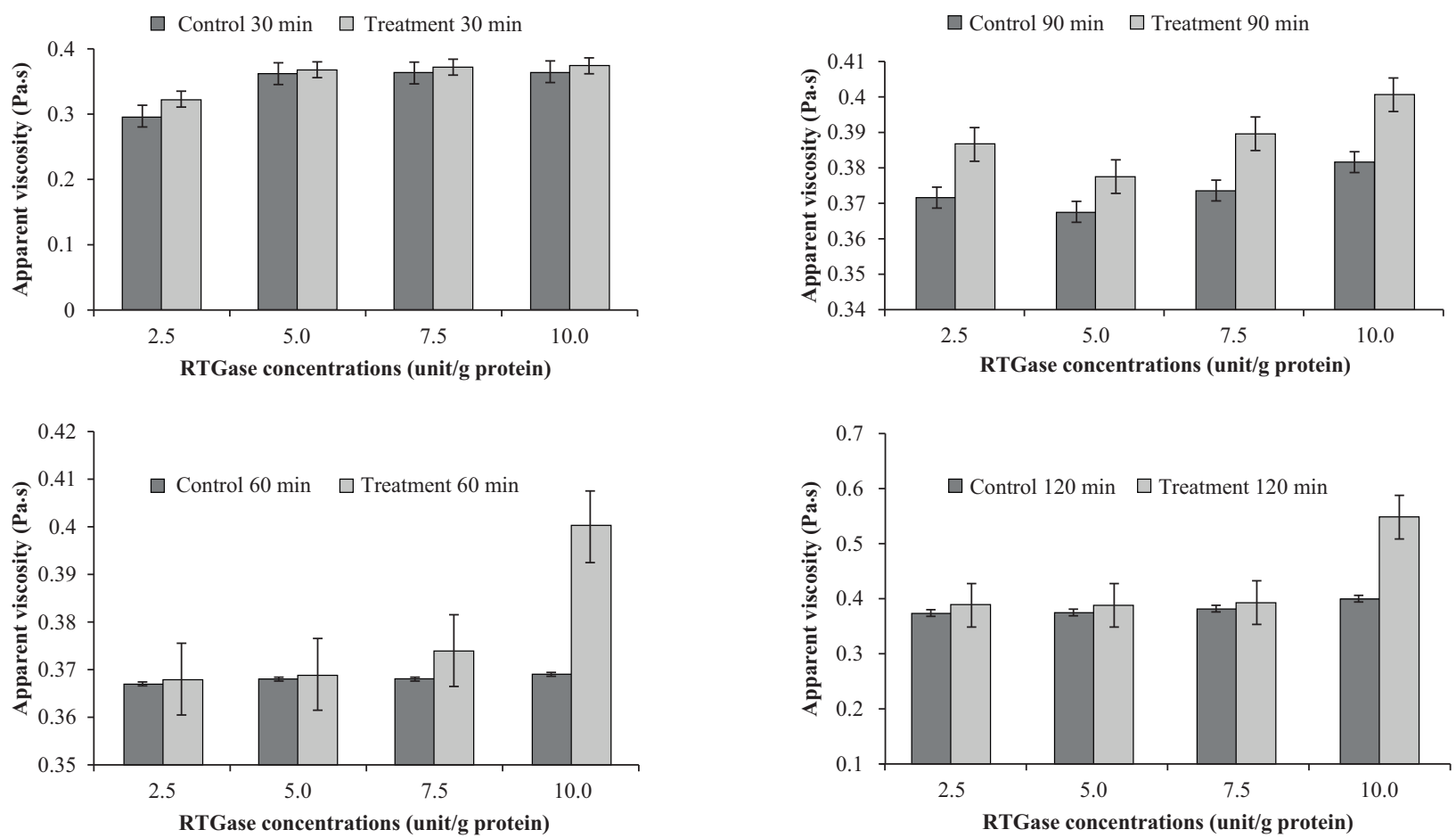

FIGURE 1. Apparent viscosity of $8 \%$ WPI solution treated with different concentrations and incubation time of RTGase at $40^{\circ} \mathrm{C}$.
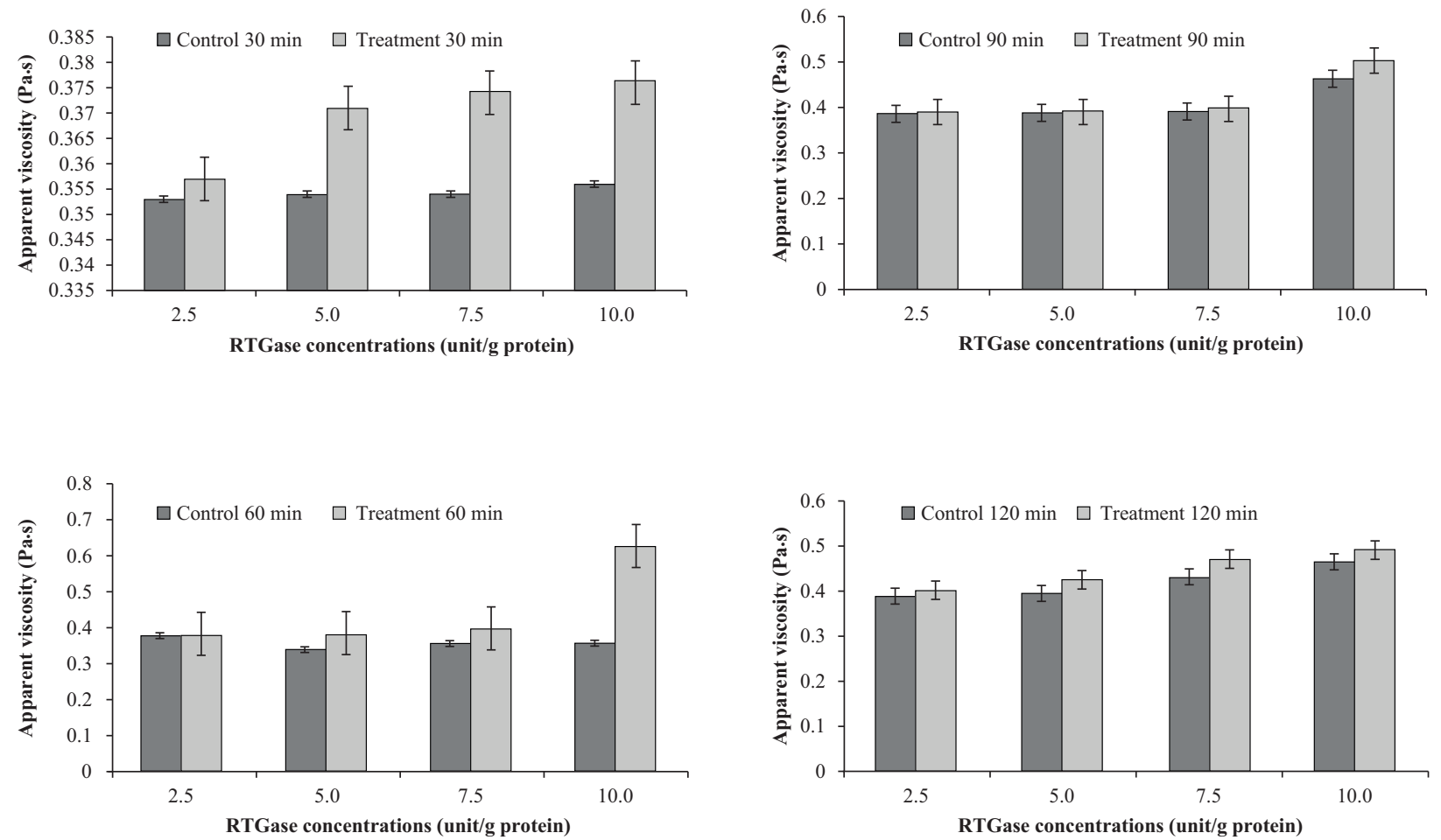

FIGURE 2. Apparent viscosity of $8 \%$ WPI solution treated with different concentrations and incubation time of RTGase at $55^{\circ} \mathrm{C}$.

values of the WPI gel cross-linked with 2.5 unit of RTGase/g protein at $55^{\circ} \mathrm{C}$ were significantly $(p \leq 0.05)$ higher than these of the untreated WPI gel. This means that RTGase treatment strengthened the gel, which could be a result of stronger polymerization of proteins. Hernàndez-Balada et al. [2009] showed that the addition of gelatin to $10 \%$ WPI caused a synergistic increase in both viscosity and the gel elastic modulus
(G'), with the formation of gels at concentrations greater than $1.5 \%$ added gelatin. The apparent viscosity of WPI solution treated with 10 units of RTGase/g protein was significantly $(p \leq 0.05)$ higher than of the control WPI incubated for $60 \mathrm{~min}$ at $55^{\circ} \mathrm{C}$.

Table 1 shows texture profile analysis (TPA) of WPI gel obtained after RTGase addition at the level of 10 unit per g protein 
for $60 \mathrm{~min}$ at $55^{\circ} \mathrm{C}$. Most of the TPA parameters, hardness, gumminess, fracturability, chewiness and resilience of the WPI gel treated with RTGase were higher than these determined for the WPI untreated with TGase with significant $(p \leq 0.05)$ differ-

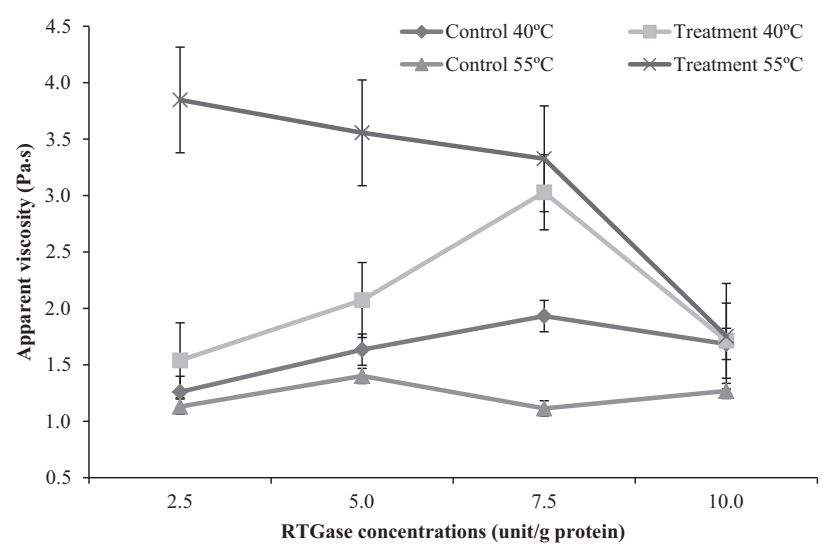

FIGURE 3. Apparent viscosity of WPI gel treated with RTGase at the level of $(2.5,5.0,7.5$ and 10.0) unit per g protein incubated at 30, 60, 90 and $120 \mathrm{~min}$, respectively at 40 and $55^{\circ} \mathrm{C}$.

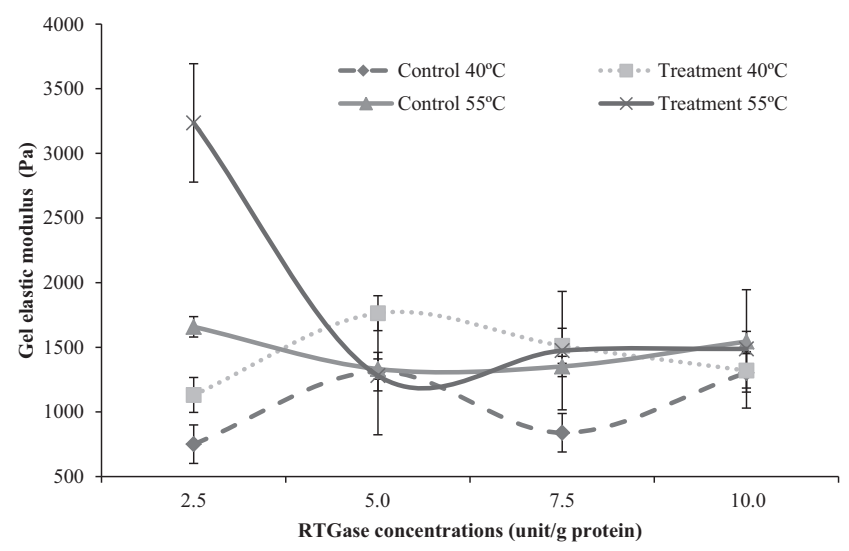

FIGURE 4. Gel elastic modulus (G') of WPI gel treated with RTGase at the level of $(2.5,5.0,7.5$ and 10.0) unit per g protein incubated at 30,60, 90 and $120 \mathrm{~min}$, respectively at 40 and $55^{\circ} \mathrm{C}$.

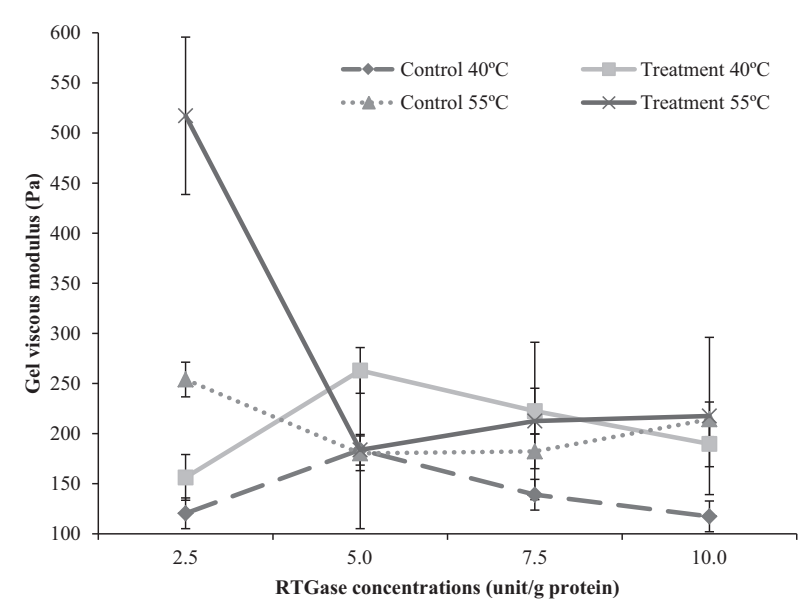

FIGURE 5. Gel viscous modulus (G") of WPI gel treated RTGase at the level of (2.5, 5.0, 7.5 and 10) unit per g protein incubated at 30, 60, 90 and $120 \mathrm{~min}$, respectively at 40 and $55^{\circ} \mathrm{C}$. ences in hardness and gumminess. It could be due to the formation of high molecular weight polymers whereas TGase enzyme catalyzed the formation of inter- and intra-molecular bonds between the protein molecules [Ando et al., 1989]. However, cohesiveness and springiness of the WPI gel treated with RTGase were significantly $(p \leq 0.05)$ lower than these noted for the WPI gel untreated with TGase.

\section{Influence of RTGase cross-linking of milk proteins on the set-type yoghurt}

Impact of RTGase cross-linked milk proteins on the yoghurt fermentation time

The fermentation curve of skim milk fortified with WPI as a control, compared to yoghurt milk treated with RTGase at the level of 2.5 and 10 unit/g protein and incubated for 30 and $60 \mathrm{~min}$, respectively is shown in Figure 6. It shows a typical decrease in $\mathrm{pH}$ from 6.6 to 4.6 within 300 min fermentation. The fermentation time of cross-linked yoghurt

TABLE 1. Parameters of the texture profile analysis obtained from the WPI gel treated with RTGase.

\begin{tabular}{l|cc}
\hline \multirow{2}{*}{ Parameters* } & \multicolumn{2}{|c}{ WPI gel samples } \\
\cline { 2 - 3 } & Control & Treated \\
\hline Hardness (g) & $13.728 \pm 0.428^{\mathrm{b}}$ & $27.820 \pm 0.935^{\mathrm{a}}$ \\
Cohesiveness (g) & $0.583 \pm 0.063^{\mathrm{a}}$ & $0.572 \pm 0.012^{\mathrm{a}}$ \\
Fracturability & $2.696 \pm 0.414^{\mathrm{a}}$ & $3.179 \pm 0.726^{\mathrm{a}}$ \\
Springiness (g) & $1.025 \pm 0.157^{\mathrm{a}}$ & $0.952 \pm 0.007^{\mathrm{a}}$ \\
Gumminess (N) & $11.223 \pm 0.779^{\mathrm{b}}$ & $14.809 \pm 0.12^{\mathrm{a}}$ \\
Chewiness (N) & $11.829 \pm 1.455^{\mathrm{a}}$ & $14.402 \pm 0.347^{\mathrm{a}}$ \\
Resilience & $0.151 \pm 0.074^{\mathrm{a}}$ & $0.252 \pm 0.005^{\mathrm{a}}$ \\
\hline
\end{tabular}

*All parameters are represented as means \pm standard error from four determinations. Means in the same line with different superscript letters are significantly different at $p \leq 0.05$. Control, WPI gel without RTGase; Treated, WPI gel treated with 10 unit RTGase per g protein at $55^{\circ} \mathrm{C}$ for $60 \mathrm{~min}$.

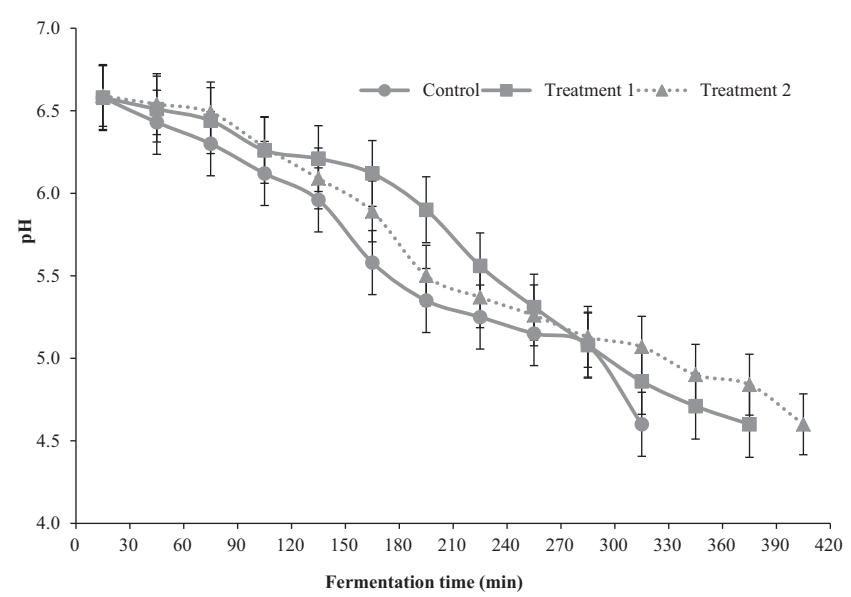

FIGURE 6. pH changes during the fermentation of yoghurt milk treated with RTGase enzyme. (Control, yoghurt sample without RTGase; T1, yoghurt sample treated with 2.5 Unit RTGase/g protein for $30 \mathrm{~min}$; T2, yoghurt sample treated with 10 Unit RTGase/g protein for $60 \mathrm{~min}$ ). 
milk increased compared to the untreated yoghurt milk, T1 (yoghurt treated with 2.5 unit RTGase/g protein for $30 \mathrm{~min}$ ) was fermented within 360 min but T2 (yoghurt treated with 10 unit RTGase/g protein for $60 \mathrm{~min}$ ) was fermented within 390 min, which is in agreement with Færgemand et al. [1997], Ozer et al. [2007] and Iličić et al. [2008] who demonstrated that the enzymatic cross-linking step led to a minor imbalance of the associative growth of the yoghurt starter culture, leading to an increase of fermentation time. The authors stated that the low molecular weight peptides and/or amino acids that are required by the lactic acid bacteria for their growth, were cross-linked by mTGase and became partially unavailable for the lactic acid bacteria, thus this slowed down the growth. On the contrary, Bönisch et al. [2007a,b], Wroblewska et al. [2011], and Tsevdou et al. [2013] observed no interference of mTGase with starter bacteria during fermentation time of yoghurt.

\section{Chemical characterization of yoghurt}

The addition of WPI powder to yoghurt milk leads to a shift in the total solids (TS), protein content and casein to whey proteins ratio (CWP) in the yoghurt matrix with $4.3 \%$ of yoghurt protein content from $3.5 \%$ of cow's milk only. The yoghurt samples manufactured and submitted to enzymatic treatment with RTGase presented TS values sig- nificantly the same as the values obtained for their untreated yoghurt (control) as shown in Table 2.

As a result of acid formation during cold storage of yoghurt, the $\mathrm{pH}$ of the cross-linked and non cross-linked yoghurt decreased from 4.6 directly after cooling to 4.4 within one week as presented in Table 3 . No significantly $(p \leq 0.05)$ differences in $\mathrm{pH}$ during storage were measurable for yoghurt samples treated or untreated with RTGase. These observations are in accordance with the study from Ozer et al. [2007] and Bönisch et al. [2007a,b] who reported that no differences in $\mathrm{pH}$ during storage were measurable for yoghurt samples with or without TGase. Lorenzen \& Schlimme [1998] also did not observe any significant differences among yoghurts with and without TGase in respect to acidity through storage period for 14 days.

Table 4 shows the fat and ash contents of set-type yoghurt treated with RTGase. There were no significant $(p \leq 0.05)$ differences between the control and the treated yoghurts. The ash content of control yoghurt had the lowest values compared to all treated yoghurts $(p \leq 0.05)$; it could be due to the mineral content of rosemary extract.

\section{Rheological properties of yoghurt}

Viscosity changes of set-type yoghurt fortified with WPI and treated with RTGase enzyme during storage at $5^{\circ} \mathrm{C}$ for

TABLE 2. Total solids (TS) and total protein (TP) of set-type yoghurt treated with RTGase.

\begin{tabular}{|c|c|c|c|c|c|c|c|}
\hline \multirow{2}{*}{ Parameters* } & \multirow{2}{*}{ Yoghurt samples } & \multicolumn{6}{|c|}{ Storage period (day) } \\
\hline & & 1 & 3 & 5 & 7 & 10 & 15 \\
\hline \multirow{3}{*}{$\mathrm{TS}(\%)$} & Control & $12.07 \pm 0.47^{\mathrm{a}}$ & $12.09 \pm 0.32^{\mathrm{a}}$ & $12.11 \pm 0.41^{\mathrm{a}}$ & $12.14 \pm 0.41^{\mathrm{a}}$ & $12.18 \pm 0.33^{\mathrm{a}}$ & $12.19 \pm 0.28^{\mathrm{a}}$ \\
\hline & $\mathrm{T} 1$ & $12.21 \pm 0.32^{\mathrm{a}}$ & $12.25 \pm 0.08^{a}$ & $12.28 \pm 0.32^{\mathrm{a}}$ & $12.30 \pm 0.17^{\mathrm{a}}$ & $12.38 \pm 0.15^{\mathrm{a}}$ & $12.41 \pm 0.09^{a}$ \\
\hline & $\mathrm{T} 2$ & $12.46 \pm 0.68^{\mathrm{a}}$ & $12.48 \pm 0.03^{\mathrm{a}}$ & $12.51 \pm 0.02^{\mathrm{a}}$ & $12.55 \pm 0.30^{\mathrm{a}}$ & $12.57 \pm 0.27^{\mathrm{a}}$ & $12.60 \pm 0.22^{\mathrm{a}}$ \\
\hline \multirow{3}{*}{$\mathrm{TP}(\%)$} & Control & $4.26 \pm 0.24^{\mathrm{a}}$ & $4.28 \pm 0.06^{\mathrm{a}}$ & $4.29 \pm 0.07^{\mathrm{a}}$ & $4.31 \pm 0.06^{\mathrm{a}}$ & $4.34 \pm 0.05^{\mathrm{a}}$ & $4.34 \pm 0.01^{\mathrm{a}}$ \\
\hline & $\mathrm{T} 1$ & $4.31 \pm 0.18^{a}$ & $4.34 \pm 0.09^{a}$ & $4.36 \pm 0.14^{\mathrm{a}}$ & $4.37 \pm 0.003^{\mathrm{a}}$ & $4.39 \pm 0.05^{\mathrm{a}}$ & $4.41 \pm 0.04^{\mathrm{a}}$ \\
\hline & $\mathrm{T} 2$ & $4.35 \pm 0.14^{\mathrm{a}}$ & $4.36 \pm 0.15^{\mathrm{a}}$ & $4.38 \pm 0.04^{\mathrm{a}}$ & $4.41 \pm 0.07^{\mathrm{a}}$ & $4.42 \pm 0.14^{\mathrm{a}}$ & $4.44 \pm 0.07^{\mathrm{a}}$ \\
\hline
\end{tabular}

* All values correspond to the mean values means \pm standard error obtained from two repetitions in triplicate. Means of parameter in the same column with different superscript letters are significantly different at $p \leq 0.05$. Control, yoghurt sample without RTGase; T1, yoghurt sample treated with 2.5 unit RTGase/g protein for $30 \mathrm{~min}$; T2, yoghurt sample treated with 10 unit RTGase/g protein for $60 \mathrm{~min}$; TP, Total protein; TS, total solids.

TABLE 3. Titratable acidity and $\mathrm{pH}$ values of set-type yoghurt treated with RTGase.

\begin{tabular}{l|c|c|c|c|c|c|c}
\hline \multirow{2}{*}{ Parameters* $^{*}$} & \multirow{2}{*}{ Yoghurt samples } & \multicolumn{6}{c}{ Storage period (day) } \\
\cline { 3 - 8 } & & 1 & 3 & 5 & 7 & 10 & 15 \\
\hline \multirow{2}{*}{$\begin{array}{l}\text { Titratable } \\
\text { acidity (\%) }\end{array}$} & Control & $0.70 \pm 0.011^{\mathrm{g}}$ & $0.79 \pm 0.017^{\mathrm{fg}}$ & $0.85 \pm 0.024^{\mathrm{ef}}$ & $0.91 \pm 0.024^{\mathrm{de}}$ & $0.93 \pm 0.015^{\mathrm{d}}$ & $1.05 \pm 0.035^{\mathrm{ab}}$ \\
& $\mathrm{T} 1$ & $0.74 \pm 0.032^{\mathrm{g}}$ & $0.79 \pm 0.040^{\mathrm{fg}}$ & $0.86 \pm 0.030^{\mathrm{ef}}$ & $0.93 \pm 0.013^{\mathrm{de}}$ & $1.04 \pm 0.013^{\mathrm{d}}$ & $1.05 \pm 0.013^{\mathrm{ab}}$ \\
& $\mathrm{T} 2$ & $0.77 \pm 0.027^{\mathrm{fg}}$ & $0.96 \pm 0.023^{\mathrm{cd}}$ & $0.99 \pm 0.013^{\mathrm{bcd}}$ & $1.00 \pm 0.023^{\mathrm{bcd}}$ & $1.05 \pm 0.013^{\mathrm{b}}$ & $1.09 \pm 0.013^{\mathrm{a}}$ \\
\hline \multirow{2}{*}{$\mathrm{pH}$} & Control & $4.55 \pm 0.008^{\mathrm{a}}$ & $4.49 \pm 0.032^{\mathrm{a}}$ & $4.43 \pm 0.020^{\mathrm{b}}$ & $4.42 \pm 0.015^{\mathrm{b}}$ & $4.42 \pm 0.015^{\mathrm{b}}$ & $4.31 \pm 0.024^{\mathrm{d}}$ \\
& $\mathrm{T} 1$ & $4.52 \pm 0.012^{\mathrm{a}}$ & $4.49 \pm 0.026^{\mathrm{a}}$ & $4.42 \pm 0.015^{\mathrm{ab}}$ & $4.40 \pm 0.008^{\mathrm{bc}}$ & $4.35 \pm 0.015^{\mathrm{b}}$ & $4.31 \pm 0.029^{\mathrm{b}}$ \\
& $\mathrm{T} 2$ & $4.50 \pm 0.012^{\mathrm{a}}$ & $4.41 \pm 0.018^{\mathrm{b}}$ & $4.40 \pm 0.014^{\mathrm{bc}}$ & $4.38 \pm 0.012^{\mathrm{bc}}$ & $4.31 \pm 0.024^{\mathrm{b}}$ & $4.25 \pm 0.023^{\mathrm{e}}$ \\
\hline
\end{tabular}

* All values correspond to the mean values means \pm standard error obtained from two repetitions in triplicate. Means of parameter in the same column with different superscript letters are significantly different at $p \leq 0.05$. Control, yoghurt sample without RTGase; T1, yoghurt sample treated with 2.5 unit RTGase/g protein for $30 \mathrm{~min}$; T2, yoghurt sample treated with 10 unit RTGase/g protein for $60 \mathrm{~min}$. 
TABLE 4. Fat and ash contents of set-type yoghurt treated with RTGase.

\begin{tabular}{|c|c|c|c|c|c|c|c|}
\hline \multirow{2}{*}{ Parameters* } & \multirow{2}{*}{$\begin{array}{l}\text { Yoghurt } \\
\text { samples }\end{array}$} & \multicolumn{6}{|c|}{ Storage period (day) } \\
\hline & & 1 & 3 & 5 & 7 & 10 & 15 \\
\hline \multirow{3}{*}{ Fat $(\%)$} & Control & $1.87 \pm 0.07^{\mathrm{a}}$ & $1.87 \pm 0.07^{\mathrm{a}}$ & $1.87 \pm 0.07^{\mathrm{a}}$ & $1.87 \pm 0.07^{\mathrm{a}}$ & $1.87 \pm 0.07^{\mathrm{a}}$ & $1.87 \pm 0.07^{\mathrm{a}}$ \\
\hline & $\mathrm{T} 1$ & $1.87 \pm 0.07^{\mathrm{a}}$ & $1.87 \pm 0.12^{\mathrm{a}}$ & $1.90 \pm 0.06^{\mathrm{a}}$ & $1.90 \pm 0.06^{\mathrm{a}}$ & $1.90 \pm 0.06^{\mathrm{a}}$ & $1.90 \pm 0.06^{\mathrm{a}}$ \\
\hline & $\mathrm{T} 2$ & $1.90 \pm 0.06^{\mathrm{a}}$ & $1.90 \pm 0.10^{\mathrm{a}}$ & $1.90 \pm 0.06^{\mathrm{a}}$ & $1.90 \pm 0.06^{\mathrm{a}}$ & $1.93 \pm 0.09^{\mathrm{a}}$ & $1.93 \pm 0.09^{\mathrm{a}}$ \\
\hline \multirow{3}{*}{ Ash (\%) } & Control & $0.946 \pm 0.003^{\mathrm{g}}$ & $0.946 \pm 0.002^{\mathrm{g}}$ & $0.946 \pm 0.002^{\mathrm{g}}$ & $0.947 \pm 0.001^{\mathrm{g}}$ & $0.948 \pm 0.002^{\mathrm{g}}$ & $0.949 \pm 0.003^{\mathrm{g}}$ \\
\hline & $\mathrm{T} 1$ & $1.032 \pm 0.001^{\mathrm{f}}$ & $1.033 \pm 0.001^{\mathrm{f}}$ & $1.035 \pm 0.003^{\mathrm{f}}$ & $1.036 \pm 0.003^{\mathrm{f}}$ & $1.101 \pm 0.001^{\mathrm{f}}$ & $1.103 \pm 0.002^{\mathrm{e}}$ \\
\hline & $\mathrm{T} 2$ & $1.210 \pm 0.0003^{\mathrm{d}}$ & $1.212 \pm 0.001^{\mathrm{d}}$ & $1.215 \pm 0.004^{\mathrm{cd}}$ & $1.221 \pm 0.0005^{\mathrm{bc}}$ & $1.227 \pm 0.004^{\mathrm{cd}}$ & $1.230 \pm 0.003^{\mathrm{a}}$ \\
\hline
\end{tabular}

* All values correspond to the mean values means \pm standard error obtained from two repetitions in triplicate. Means of parameter in the same column with different superscript letters are significantly different at $p \leq 0.05$. Control, yoghurt sample without RTGase; T1, yoghurt sample treated with 2.5 unit RTGase/g protein for $30 \mathrm{~min}$; T2, yoghurt sample treated with 10 unit RTGase/g protein for 60 min.

15 days are shown in Figure 7. It could be observed that the proportional increase in RTGase concentration added to yoghurt caused a gradual significant $(p \leq 0.05)$ increase in apparent viscosity of the final yoghurt product compared with the control yoghurt during storage period. Overall, viscosity values of RTGase-treated yoghurt were higher than these of the untreated yoghurt; it could be due to an increase of TS resulting from the addition of WPI powder to yoghurt milk and the cross-linking reaction by RTGase, which is in agreement with Ozer et al. [2007], Bönisch et al. [2007a,b], Guyot \& Kulozik [2011], who reported that the viscosity of all yoghurt samples increased with protein fortification. Færgemand et al. [1997], Iličić et al. [2008], Şanli et al. [2011], and Domagała et al. [2013] also observed higher viscosity values of yoghurts treated with TGase compared to the control yoghurts.

However, the viscosity of yoghurt treated with RTGase remained nearly constant during the whole storage period and no significant changes were found. The absence of structural development can be explained by the complete enzyme inactivation prior to lactic culture addition because it had the advantage of a constant $\mathrm{pH}$ during the TGase cross-linking reaction, thus offering a wide range of possible incubation

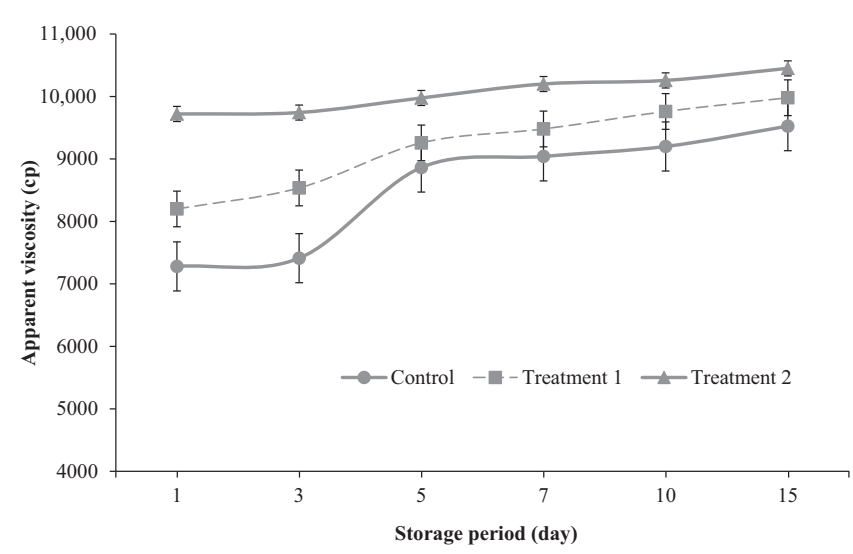

FIGURE 7. Apparent viscosity changes of set-type yoghurt treated with RTGase during storage at $5^{\circ} \mathrm{C}$ for 15 days. (Control, yoghurt sample without TGase; Treatment 1, yoghurt sample treated with 2.5 Unit RTGase/g protein for $30 \mathrm{~min}$; Treatment 2, yoghurt sample treated with 10 Unit RTGase/g protein for $60 \mathrm{~min}$ ). conditions. Similar results have been reported by Bönisch et al. [2007a,b], Guyot \& Kulozik [2011], and Şanli et al. [2011] who found that TGase inactivation prior to yoghurt fermentation leading to no formation of covalently cross-linked protein polymers occurred during yoghurt storage leading to constant viscosity of yoghurt treated with TGase. Farnsworth et al. [2006] observed that the protein cross-linking of yoghurt milk prior to fermentation can be used very effectively to improve the gel structure of set-style yoghurt.

\section{Textural properties of yoghurt}

The addition of RTGase at the level of 10 unit per g milk yoghurt protein prior to the yoghurt fermentation process showed a significant increase $(p \leq 0.05)$ in hardness (Table 5), these findings may be due to the additional $\varepsilon$-( $\gamma$-glutamyl) lysine bonds created by TGase [Gauche et al., 2009]. There were no significantly differences $(p \leq 0.05)$ between treated and untreated yoghurt with RTGase in cohesiveness, springiness, gumminess, chewiness and resilience. Lauber et al. [2000] suggested that protein cross-linking predominantly occurred inter-molecularly and the increased stress required to break the yoghurt gel was correlated with the level of ca-

TABLE 5. Texture profile analysis of set-type yoghurts treated with RTGase.

\begin{tabular}{l|c|c}
\hline \multirow{2}{*}{ Parameter * } & \multicolumn{2}{|c}{ Yoghurt samples } \\
\cline { 2 - 3 } & Control & Treated \\
\hline Hardness (g) & $42.314 \pm 1.08^{\mathrm{b}}$ & $47.280 \pm 0.76^{\mathrm{a}}$ \\
Cohesiveness (g) & $0.465 \pm 0.007^{\mathrm{a}}$ & $0.420 \pm 0.014^{\mathrm{a}}$ \\
Springiness (g) & $0.961 \pm 0.0008^{\mathrm{a}}$ & $0.960 \pm 0.011^{\mathrm{a}}$ \\
Gumminess (N) & $19.419 \pm 0.276^{\mathrm{a}}$ & $19.643 \pm 0.374^{\mathrm{a}}$ \\
Chewiness (N) & $18.66 \pm 0.280^{\mathrm{a}}$ & $18.62 \pm 0.204^{\mathrm{a}}$ \\
Resilience & $0.028 \pm 0.00^{\mathrm{a}}$ & $0.027 \pm 0.002^{\mathrm{a}}$ \\
\hline
\end{tabular}

*All parameters represented as means \pm standard error from four determinations. Means in the same line with different superscript letters are significantly different at $p \leq 0.05$. Control, yoghurt sample without TGase; Treated, yoghurt sample treated with 10 unit RTGase per g protein at $55^{\circ} \mathrm{C}$ for $60 \mathrm{~min}$. 


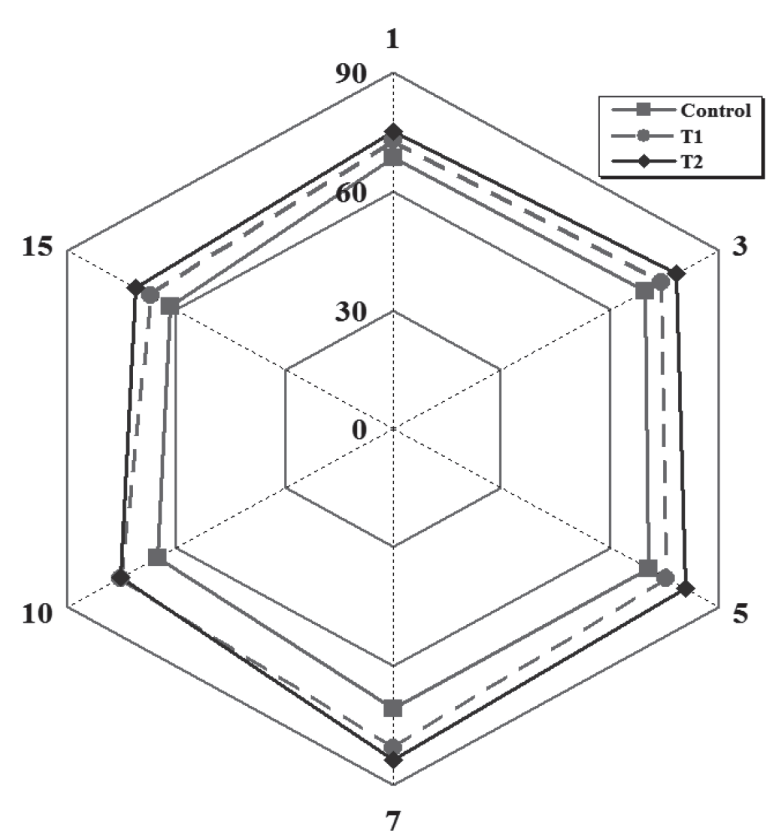

FIGURE 8. Organoleptic properties of set-type yoghurt treated with RTGase during storage at $5^{\circ} \mathrm{C}$ for 15 days. Control, yoghurt sample without RTGase; T1, yoghurt sample treated with 2.5 unit RTGase/g protein for 30 min; T2, yoghurt sample treated with 10 unit RTGase/g protein for $60 \mathrm{~min}$. (Each point describes collective score for each sample per day including appearance, color, body \& texture, flavor, and overall acceptability).

sein oligomerization catalyzed by TGase, which increases according to the enzymatic reaction time. The introduction of new covalent bonds to milk protein systems using TGase can produce acid milk gels with different textural properties when compared with traditionally manufactured gels, especially when the chemical composition is changed.

\section{Organoleptic properties of yoghurt}

The total scores of organoleptic results including appearance, color, flavor, body, texture and overall acceptability of set-type yoghurt in the presence and absence of RTGase are given in Figure 8. During the storage period, all panelists preferred the cross-linked yoghurt treated with RTGase compared to the control yoghurt but T2 (yoghurt treated with 10 unit RTGase/g protein for $60 \mathrm{~min}$ ) had the highest score compared to the control and other treatment (T1, yoghurt treated with 2.5 unit RTGase/g protein for $30 \mathrm{~min}$ ). Similar findings were observed by Ozer et al. [2007] who found that the yoghurts treated with higher concentration of mTGase received higher scores compared to a lower dose of the same enzyme and found to be fairly similar to the control yoghurt. TGase concentrations in the range of 9-14 unit/g protein were used in multiple studies to improve the physical, chemical and sensory properties of set-style yoghurt compared to untreated yoghurt [Lorenzen et al., 2002]. Also, the results obtained indicated that at the $7^{\text {th }}$ day the samples treated with RTGase enzyme had the highest scores through the storage period, afterwards the total scores were decreased but the products were still acceptable. Body and texture scores of set-type yoghurt were enhanced in the samples treated with RTGase enzyme and there were significant $(p \leq 0.05)$ differ-

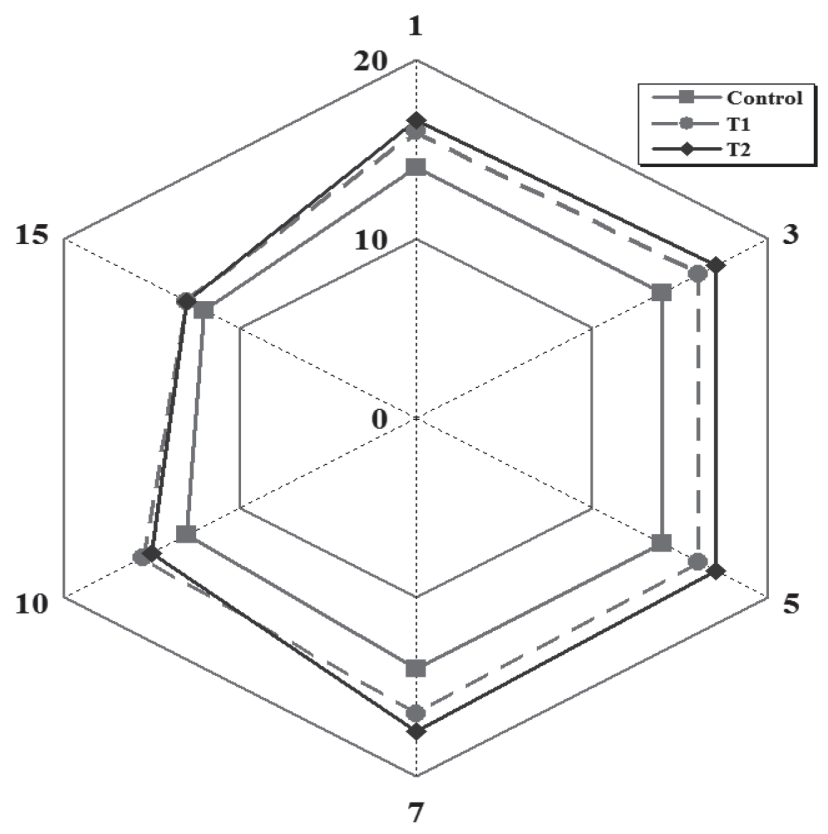

FIGURE 9. Body and texture changes of set-type yoghurt treated with RT-Gase during storage at $5^{\circ} \mathrm{C}$ for 15 days. Control, yoghurt sample without RTGase; T1, yoghurt sample treated with 2.5 unit RTGase/g protein for $30 \mathrm{~min}$; T2, yoghurt sample treated with 10 unit RTGase/g protein for $60 \mathrm{~min}$. (Each point describes collective score for each sample per day of body and texture).

ences at the $7^{\text {th }}$ day among control yoghurt and all treatments but no differences between treatments (Figure 9).

\section{CONCLUSION}

It could be concluded that the RTGase can be used as an enzymatic modification tool of whey proteins as the study has shown that the viscosity and gel characteristics where improved compared to whey protein untreated with RTGase. Also, the texture profile analysis of WPI gel obtained showed that hardness, gumminess, fracturability, chewiness and resilience of WPI gel treated with RTGase were higher than these of the WPI untreated with RTGase. Moreover, the chemical and rheological properties of final yoghurt fortified with WPI and cross-linked with RTGase were improved compared to the control yoghurt. Also, the results demonstrated that the shelf life of final set-type yoghurt treated with RTGase could be consumed during 15 days of storage at $5^{\circ} \mathrm{C}$ because no defects appeared during this period but it could be recommended to use it during the first week.

\section{ACKNOWLEDGEMENTS}

The Egyptian authors kindly thank Prof. Dr. Pawel Glibowski for helpful guidance, encouragement and technical assistance throughout this work at the University of Life Sciences in Lublin, Poland. Moreover, for his valuable and critical comments during manuscript preparation.

The corresponding author would like to express special thanks to Prof. Dr. Azza A. Ismail (God's mercy), Researcher Professor of Dairy Chemistry (Enzymes), National Research 
Centre in Egypt, for her encouragement, plentiful advice, valuable suggestion and moral support during her life.

\section{RESEARCH FUNDING}

This work was funded by National Research Centre, Egypt and by the University of Life Sciences in Lublin, Poland.

\section{CONFLICT OF INTEREST}

Authors declare no conflict of interest.

\section{REFERENCES}

1. Ando H., Adachi M., Umeda K., Matsuura A., Nonaka M., Uchio R, Purification and characterization of a novel transglutaminase derived from micro-organisms. Agric. Biol. Chem., 1989, 53, 2613-2617.

2. AOAC, Official Methods of Analysis. (16 $\left.6^{\text {thed }}\right) .1995$, Arlington, VA, USA: Association of Official Analytical Chemists.

3. Bönisch M.P., Huss M., Lauber S., Kulozik U., Yoghurt gel formation by means of enzymatic protein cross-linking during microbial fermentation. Food Hydrocoll., 2007a, 21, 585-595.

4. Bönisch M.P., Huss M., Weld K., Kulozik U., Transglutaminase cross-linking of milk proteins and impact on yoghurt gel properties. Int. Dairy J., 2007b, 17, SI, 1360-1371.

5. Del Duca S., Serafini-Fracassini D., Transglutaminases of higher, lower plants and fungi. 2005, in: Transglutaminases Family of Enzymes with Diverse Functions (eds. K. Mehta, R. Eckert). Karger, Basel, Switzerland. Prog. Tumor Res., 2005, 38, 223-247.

6. Del Duca S., Serafini-Fracassini D., Bonner P., Cresti M., Cai G., Effects of post-translational modifications catalysed by pollen transglutaminase on the functional properties of microtubules and actin filaments. Biochem. J., 2009, 418, 651-664.

7. Di Sandro A., Del Duca S., Verderio E., Hargreaves A., Scarpellini A., Cai G., Cresti M., Faleri C., Iorio R., Hirose S., Furutani Y., Coutts L., Griffin M., Bonner P., Serafini-Fracassini D., An extracellular transglutaminase is required for apple pollen tube growth. Biochem. J., 2010, 429, 261-271.

8. Domagała J., Wszołek M., Tamime A.Y., Kupiec-Teahan B., The effect of transglutaminase concentration on the texture, syneresis and microstructure of set-type goat's milk yoghurt during the storage period. Small Rum. Res., 2013, 112, 154-161.

9. Eissa A.S., Khan S.A., Modulation of hydrophobic interactions in denatured whey proteins by transglutaminase enzyme. Food Hydrocoll., 2006, 20, 543-547.

10. El-Hofi M., Ismail A., Nour M., Ibrahim O., Isolation, purification and characterization of transglutaminase from rosemary (Rosmarinus officinalis L.) leaves. Acta Sci. Pol. Technol. Alim., 2014, 13, 267-278.

11. Færgemand M., Qvist K.B., On the importance of using $\mathrm{Ca}^{+2}$-independent transglutaminase for cross-linking of $\beta$-lactoglobulin. Food Hydrocoll., 1999, 13, 199-201.

12. Færgemand M., Otte J., Qvist K.B., Enzymatic cross-linking of whey proteins by a $\mathrm{Ca}^{+2}$-indpendent microbial transglutaminase from Streptomyceslydicus. Food Hydrocoll., 1997, 11, 19-25.

13. Farnsworth J.P., Li J., Hendricks G.M., Guo M.R., Effects of transglutaminase treatment on functional properties and pro- biotic culture survivability of goat milk yogurt. Small Rum. Res., 2006, 65, 113-121.

14. Folk J.E., Cole P.W., Identification of a functional cysteine essential for the activity of guinea pig liver transglutaminase. J. Biol. Chem., 1966, 241, 3238-3240.

15. Gauche C., Barreto P.L.M., Bordignon-Luiz M.T., Effect of thermal treatment on whey protein polymerization by transglutaminase: Implications for functionality in processed dairy foods. LWT-Food Sci. Technol., 2010, 43, 214-219.

16. Gauche C., Tomazi T., Barreto P.L.M., Ogliari P.J., Bordignon-Luiz M.T., Physical properties of yoghurt manufactured with milk whey and Transglutaminase. LWT-Food Sci. Technol., 2009, 42, 239-243.

17. Genena A.K., Hense H., Smânia Junior A., Machado de Souza S., Rosemary (Rosmarinus officinalis) - a study of the composition, antioxidant and antimicrobial activities of extracts obtained with supercritical carbon dioxide. Ciência Tecnol. Alime., 2008, 28, 463-469.

18. Griffin M., Casadio R., Bergamini C.M., Transglutaminases: Nature's biological glues. Biochem. J., 2002, 368, 377-396.

19. Guyot C., Kulozik U., Effectof transglutaminase-treated milk powders on thepropertiesofskim milk yoghurt. Int. Dairy J., 2011, 21, 628-635.

20. Ha G., Iuchi I., Transglutaminase. 2003, in: Handbook of Food Enzymology (eds. J.R. Whitaker, A.G. Voragen, D.W.S. Wong). Marcel Dekker, Inc., Basel, New York, p. 51.

21. Hernàndez-Balada E., Taylor M.M., Phillips J.G., Marmer W.N., Properties of biopolymers produced by transglutaminase treatment of whey protein isolate and gelatin. Biores. Technol., 2009, 100, 3638-3643.

22. Iličić M.D., Carć M.D., Milanović S.D., Dokić L.P.L.J., Đurić M., Bošnjak G., Duraković K., Viscosity changes of probiotic yoghurt with transglutaminase during storage. APTEFF, 2008, 39, 11-19.

23. Iličić M.D., Milanović S.D., Caré M.D., Dokić L.P., Kanurić K.G., Effect of transglutaminase on texture and flow properties of stirred probiotic yoghurt during storage. J. Texture Stud., 2014, 45, 13-19.

24. Jaros D., Partschefeld C., Henle T., Rohm H., Transglutaminase in dairy products: chemistry, physics, applications. J. Texture Stud., 2006, 37, 113-155.

25. Kang H., Cho Y.D., Purification and properties of transglutaminase from soybean (Glycine max) leaves. Biochem. Biophys. Res. Commun., 1996, 223, 288-292.

26. Kücükcetin A., Effect of heat treatment and casein to whey protein ratio of skim milk on graininess and roughness of stirred yoghurt. Food Res. Int., 2008, 41, 165-171.

27. Lauber S., Henle T., Klostermeyer H., Relationship between the crosslinking of caseins by transglutaminase and the gel strength of yoghurt. Eur. Food Res. Technol., 2000, 210, 305-309.

28. Li-Chan E.C.Y., Properties of proteins in food systems: an introduction. 2004, in: Proteins in Food Processing (ed. R.Y. Yada). CRC Press, Boca Raton, FL, pp. 2-26.

29. Lilley G.R., Skill J., Griffin M., Philip L.R., Detection of $\mathrm{Ca}^{+2}$ -dependent transglutaminase activity in root and leaf tissue of monocotyledonous and dicotyledonous plants. Plant Physiol., 1998, 117, 1115-1123.

30. Lin S., Hsieh Y., Wang P., Chu W., Efficient purification of transglutaminase from recombinant Streptomyces platensis at various scales. Biotechnol. Lett., 2007, 29, 111-115. 
31. Lorenzen P.C., Schlimme E., Properties and potential fields of application of transglutaminase preparations in dairying. Bull. Int. Dairy Fed., 1998, 332, 47-53.

32. Lorenzen P.C., Neve H., Mautner A., Schlimme E., Effect of enzymatic cross-linking of milk proteins on functional properties of set-style yogurt. Int. J. Dairy Technol., 2002, 55, 152-157.

33. Loveday S.M., Sarkar A., Singh H., Innovative yoghurts: Novel processing technologies for improving acid milk gel texture. Trends Food Sci. Technol., 2013, 33, 5-20.

34. Maifreni M., Marino M., Pittia P., Rondinini G., Textural and sensorial characterization of Montasio cheese produced using proteolytic starters. Milchwissenchaft - Milk Sci. Int., 2002, 57, 23-26.

35. Motoki M., Kumazawa Y., Recent research trends in transglutaminase technology for food processing. Food Sci. Technol. Res., 2000, 6, 151-160.

36. Ozer B., Kirmaci H.A., Oztekin S., Hayaloglu A., Atamer M., Incorporation of microbial transglutaminase into non-fat yogurt production. Int. Dairy J., 2007, 17, 199-207.

37. Şanli T., Sezgin E., Deveci O., Şenel E., Benli M., Effect of using transglutaminase on physical, chemical and sensory properties of set-type yoghurt. Food Hydrocoll., 2011, 25, 1477-1481.

38. SAS Institute, SAS User's Guid / STAT. 1990, Ver. 6.04, $4^{\text {th }}$ ed., SAS Inst. Inc. Cary, NC.

39. Serafini-Fracassini D., Del Duca S., Transglutaminases: widespread cross-linking enzymes in plants. Ann. Bot., 2008, 102 $145-152$.
40. Serafini-Fracassini D., Del Duca S., Monti F., Poli F., Sacchetti G., Bregoli A., Biondi S., Della Mea M., Transglutaminase activity during senescence and programmed cell death in the corolla of tobacco (Nicotiana tabacum) flowers. Cell Death Differ., 2002, 9, 309-321.

41. Signorini M., Beninati S., Bergamini D., Identification of transglutaminase activity in the leaves of Silver Beet (Beta vulgaris L.). J. Plant Physiol., 1991, 137, 547-552.

42. Truong V.D., Clare D.A., Catignani G.L., Swaisgood H.E., Cross-linking and rheological changes of whey proteins treated with microbial transglutaminase. J. Agr. Food Chem., 2004, 52, 1170-1175.

43. Tsevdou M.S., Eleftheriou E.G., Taoukis P.S., Transglutaminase treatment of thermally and high pressure processed milk: Effects on the properties and storage stability of set yoghurt. Food Sci. Emerg. Technol., 2013, 17 144-152.

44. Wilcox C.P., Swaisgood H.E., Modification of the rheological properties of whey protein isolate through the use of an immobilized microbial transglutaminase. J. Agric. Food Chem., 2002, 50, 5546-5551.

45. Wróblewska B., Kaliszewska A., Kołakowski P., Pawlikowska K., Troszyńska A., Impact of transglutaminase reaction on the immunoreactive and sensory quality of yoghurt starter. World J. Microbiol. Biotechnol., 2011, 27, 215-227.

Submitted: 9 November 2015. Revised: 15 March and 4 May 2016. Accepted: 5 May 2016. Published on-line: 21 April 2017. 